https://doi.org/10.52326/jss.utm.2021.4(1).09 UDC 159.955

\title{
FOUND: A DEFINITION OF INTELLIGENCE
}

\author{
Adewunmi Falode*, ORCID ID: 0000-0003-0649-1042 \\ ${ }^{1}$ Lagos State University, Ojo, Lagos, Nigeria \\ *Corresponding author: Adewunmi Falode, adewunmi.falode@lasu.edu.ng
}

Received: 01. 17. 2021

Accepted: 02. 19. 2021

\begin{abstract}
Intelligence has come to play a pivotal role in the affairs of states and non-state actors in the $21^{\text {st }}$ century. It not only determines the outcome of conflict when it breaks out but also provides critical edge and foresight in military planning and engagements. However, the effective utilization and deployment of intelligence in any strategic environment may be hampered by the lack of a holistic and generally accepted definition of it. The search for a robust definition has not also been helped by the differing views on what should constitute the basic elements of it. To overcome these challenges, this work argues for and provides a holistic definition of intelligence. It uses both qualitative and quantitative methodologies to provide a more robust and holistic definition of intelligence. The work concludes that any acceptable definition of intelligence must contain five key elements: process, data, actionable information, political group and security.
\end{abstract}

Keywords: Intelligence, Definition, Process, Data, Actionable information

Rezumat. Inteligența a ajuns să joace un rol esențial în treburile statelor și ale actorilor nestatali în secolul XXI. Nu numai că determină rezultatul conflictului atunci când izbucnește, ci oferă și avantaje critice și previziune în planificarea și angajamentele militare. Cu toate acestea, utilizarea și desfășurarea eficientă a informațiilor în orice mediu strategic poate fi împiedicată de lipsa unei definiții holistice și general acceptate a acesteia. Căutarea unei definiții solide nu a fost, de asemenea, ajutată de opiniile diferite asupra a ceea ce ar trebui să constituie elementele de bază ale acesteia. Pentru a depăși aceste provocări, această lucrare susține și oferă o definiție holistică a inteligenței. Utilizează atât metodologii calitative cât și cantitative pentru a oferi o definiție mai robustă și holistică a inteligenței. Lucrarea concluzionează că orice definiție acceptabilă a informațiilor trebuie să conțină cinci elemente cheie: proces, date, informații acționabile, grup politic și securitate.

Cuvinte cheie: inteligență, definiție, proces, date, informații acționabile.

\section{Introduction}

What is intelligence? This looks like a simplistic question that should have a straightforward answer. However, this is not the case. Creating an acceptable definition for intelligence has been as difficult as framing acceptable definitions for other concepts in international relations. Intelligence, especially of the military variety, has come to a play crucial role in the affairs of states and non-state actors in the $21^{\text {st }}$ century. In the $20^{\text {th }}$ century, intelligence played crucial role in determining the outcomes of both the First and Second World Wars. The rise and ability of non-state actors like Al-Qaeda, Islamic State and Boko Haram to challenge and dominate established states in often violent asymmetric conflicts have further heightened the need of intelligence to effectively counter such hostile non-state groups. This brings to the fore the need for a generally accepted definition of intelligence. It is this author's considered opinion that for intelligence to be effectively and optimally wielded and deployed, there is the need to create a universally acceptable definition for it. 


\section{Search for a Definition: Old Wine, Old Bottle}

Although, there is no universally accepted definition of what intelligence is or should be, there is general agreement on what its purpose should be: to give an edge to one over an adversary or, put differently, to provide relative security and minimize risk. A qualitative and quantitative content analysis of the definitions of intelligence shows that an acceptable definition contains 15 key terms that must include words like information, end-user, actionability, foreign groups, collecting, analysis, threat and objectives [1, p. 201]. Most definitions of intelligence have adhered to the highlighted terms in one form or the other. Dokman defines intelligence as actionable knowledge of foreign countries that is disseminated in the form of information towards end users [1, p. 202]. This definition is problematic on many fronts. The first is that it assumes that intelligence activity is restricted to states, thereby neglecting the important role of non-state actors in the $21^{\text {st }}$ century. Second is the confusing use of the words 'actionable knowledge' and 'information.' This is understandable to an extent since one can deduce that the author is trying to avoid the use of the word 'intelligence' in the definition of intelligence.

Milton Diaz adheres to these by emphasizing that a definition of intelligence must contain the core elements of process, knowledge, decision-making, actor and national-security [2, p. 59]. Diaz, it should be noted, did not advance any rigid definition of intelligence. Jensen, McElreath and Graves argue that intelligence is meant to provide critical edge in decision-making that shifts the balance in favour of decision-maker [3, p. 2]. According to the authors, intelligence is meant to provide a decision advantage where one knows more than a competitor or an adversary $[3, \mathrm{p}$. 3]. This is seen as the ultimate purpose of the intelligence product. Here again, rather than give a solid definition, the authors only emphasized the purpose of the intelligence.

Michael Warner, an oft cited and respected security scholar, sees intelligence as a secret state-directed activity designed to understand or influence foreign entities [4]. It has some basic elements that include secret sources and covert method, foreign targets and production and dissemination of information [4]. One should reject this definition out of hand because of the emphasis it places on secret sources, covert method and the utility of intelligence by just the states, among others. His definition fails to acknowledge the use of intelligence by non-state actors and OSINT (open-source intelligence) as an important source of intelligence in the $21^{\text {st }}$ century. Bilandzic and Mikulic defines intelligence as the gathering, organizing and analysis of information with the ultimate aim of providing actionable product to decision-makers [5, pp. 2743]. Two critical problems with this definition are the use of 'information' and the failure to mention the name of this 'actionable product.' It is assumed the end-product will be the information and this should be the actionable product. The 'information' in the definition creates a level of ambiguity: is it as the end-product or as source of the end-product? These are not clearly stated in the definition. To Loch Jonson, intelligence is the foreknowledge sought by nations in response to external threats and to protect their well-being [6, p. 366]. True, but then, the threats to states are not always external in the $21^{\text {st }}$ century, especially when one considers what is going on between Nigeria and Boko Haram and Somalia and Al-Shabaab. Alan Breakspear defines intelligence as a corporate capability to forecast change in time to do something about it [7, p. 1]. However, apart from the fact that the definition did not conform with any of the elements in Dokman's database, it also fails to mention the specific process that is involved in gathering this intelligence. According to Mark Lowenthal intelligence refers to information that meets the stated or understood needs of policy makers and has been collected processed and narrowed to meet those needs [8, p. 23]. The author further shows that it covers four broad but interconnected activities: collection, analysis, covert action and counterintelligence. While one readily agrees with some of the elements of intelligence in the definition, the conflation of the end-product 
(intelligence) with the process that births this (information) creates a level of ambiguity. Sherma $\mathrm{n}$ Kent sees intelligence as a knowledge-gathering process meant to enhance a nation's foreign policy posture [9]. This process has three different iteration within it: unique knowledge, knowledge-collecting organization and an activity. Though, one readily agrees with Kent's use of 'process', however, restricting the use of intelligence to just nations or states renders the definition provided inadequate.

Gill and Phythian define intelligence as the range of activities conducted in secret and aimed at ensuring the security of a state [10, p. 7]. These range of activities, according to the authors, can be both active (covert actions) and passive (collection, analysis and dissemination of information). Again, one needs to emphasize that the conduct of intelligence in the $21^{\text {st }}$ century encompasses both overt and covert action. The failure to clarify this renders this definition inadequate. The United States Department of Defence (USDD) defines intelligence as a product of collecting, evaluating, analyzing, integrating and interpreting all available information relating to one or more aspects of other countries or areas of operations that is potentially useful for future planning [11]. This USDD idea is simply an explanation of the process of intelligence and it also fails to clarify the end-product.

\section{Methodology}

This research relies on both qualitative and quantitative methodologies. The qualitative aspect involves the extensive collection, collation, analysis and interpretation of secondary materials like textbooks, journal articles and internet articles on definition of intelligence. This ensures that the works of leading international specialists and scholars in the field of intelligence such as Michael Warner, Loch Johnson, Alan Breakspear and Milton Diaz were consulted and parsed in the course of the research. The quantitative methodology used made it possible, through systemic and critical content analysis of 36 definitions to identify the key elements that an acceptable definition of intelligence must contain. One should note here that 35 of the 36 definitions of intelligence used relied heavily on the intelligence database created by Tomislav Dokman. The $36^{\text {th }}$ definition is Dokman's definition of intelligence. Dokman identified 15 core elements of intelligence that include information, actionability, processing, analysis, threat, foreign countries, knowledge, confidentiality, collecting, request, dissemination, enemy, objectives, end user and national security. However, by using the quantitative methodology and content analysis, this research has been able to synthesize the core elements that an acceptable definition of intelligence must contain to just nine words: process, collection, collation, analysis, interpretation, conversion, data, political group and relative security. Three of these elements that I consider to be the core of any eventual acceptable definition of intelligence - conversation, data and political group - are missing from all the other earlier definitions of intelligence.

\section{Found: New Wine, Old Bottle}

From the foregoing, one can argue that intelligence is a tool and a means to an end. As a tool, it is used to ensure the creation of a desired favourable outcome in any environment and the end is the creation of a relatively secured environment. Since an environment, by its nature, is always dynamic and constantly in flux, that means any good intelligence must be abreast of this inconsistency. This is why an acceptable definition of intelligence must see it as a process without prejudice to the other elements highlighted by intelligence scholars. Thus, intelligence can be defined as the process of collection, collation, analysis, interpretation and conversion of raw data into actionable information by a political group with the aim of ensuring its relative security. This definition meets most of the criteria earlier arrived at through the qualitative and quantitative content analysis of the definitions of intelligence by Dokman [1]. It has five key elements: process, data, conversion, political group and relative security. 
Let me quickly explain here the use of data in the definition. The use of 'data' in the definition is particularly apposite and timely. Intelligence here is not just information, as is found in most definitions: but, processed or distilled data. Every bits of information cannot be termed as intelligence. Using information, part of the process of intelligence, interchangeably for the end-product (intelligence or actionable information), as most scholars had done, has always been problematic and obfuscatory. This has created avoidable confusion in trying to provide an acceptable definition of intelligence. To get around this, I have substituted data for the initial use of the word 'information' at the beginning of most definitions. Information in the context of this work simply means intelligence or the end-product or actionable information. Data are the bits and pieces of unprocessed or unfiltered datum collected through the techniques of intelligence. This cannot be referred to as intelligence or information or actionable information until it has been sieved. Hence, the use of the word 'data' in the definition. The raw data is obtained using the different techniques of intelligence such as HUMINT (human intelligence) or OSINT (opensource intelligence) to string datum into a coherent whole for analysis. The political group here is the end-user and could be the decision-maker, operational or theatre commander, military command, security forces, a non-state actor or the state in more concrete form. Since it is a process, it will have to be done on a continuous rolling basis to provide real-time assessment to enable the end-user take optimal decision in every situation. The distilled and converted data, now intelligence (actionable information), is obtained through the processes of collection, collation, analysis, interpretation and conversion. Of course, the result of the whole process (intelligence) is to guarantee the relative security of the end-user. One should stress here that the strategic environment and the operational capability of the state will determine the optimal intelligence-gathering techniques to be used.

\section{Conclusion}

The role of intelligence in ensuring the security of political actors in the $21^{\text {st }}$ century cannot be overemphasized. The international environment is in a constant state of flux, with unprecedented number of maligned non-state actors. Conventional methods of combating the various threats that these maligned non-state actors pose have been shown to be inadequate. The asymmetric nature of most conflicts has further put the state under increasing pressure. Intelligence is an important tool that provides political actors, especially the state, with a critical edge that ensures the preservation of its security. Hence, the need for the provision of a robust and holistic definition of intelligence to enable the end-user create a relatively secure environment.

\section{References}

1. Dokman T. Defining the Term 'Intelligence' - Insight into exisiting intelligence knowledge. In: Informatologia, 2019, 52 (3-4), pp. 201-202. [accesat 09.10.2020]. Disponibil: https://hrcak.srce.hr/file/341342

2. Diaz M. Forming a definitional framework for intelligence. In: American Intelligence Journal, 2011,29 (1), p. 59.

3. Jensen C., Mcelreath D., Graves M. Introduction to Intelligence Studies. London: Taylor \& Francis Group, 2013.

4. Warner M. Wanted a definition of intelligence. In: Studies in Intelligence, 2002, 46 (3). [accesat 12/09/20].Disponibil: https://apps.dtic.mil/dtic/tr/fulltext/u2/a525816.pdf

5. Bilandzic M., Mikulic I. Business Intelligence and National Security. In: Polemos, 2007, 10 (1), pp. 27-43.

6. Johnson L. Intelligence. In: Jentleson, B.- Peterson T. ed. Encyclopedia of U.S. foreign relations. New York: Oxford University Press1997, pp. 365-73.

7. Breakspear A. A new definition of intelligence. In: Intelligence and National Security, 2013, 28(5), pp.678-693. [accesat 03.01.21]. Disponibil: http://dx.doi.org/10.1080/02684527.2012.699285

8. Lowenthal M. Intelligence: From secrets to policy, 4th ed. Washington: CQ Press, 2009.

9. Kent S. Strategic intelligence for American world policy. New Jersey: Princeton University Press, 1949.

10. Gill P., Phythian M. Intelligence in an insecure world. Cambridge: Polity Press, 2006.

11. United States Department of Defence. Dictionary of Military and Associated Terms, 2012. [accesat 15.11.20]. Disponibil: https://www.jcs.mil/Portals/36/Documents/Doctrine/pubs/dictionary.pdf 